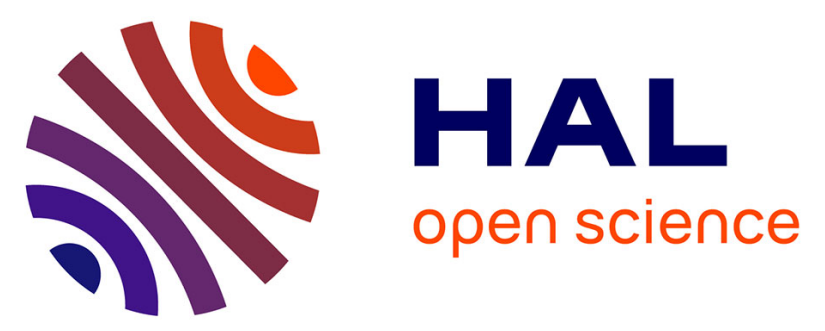

\title{
The Loyalty-New Hebrides Arc collision: Effects on the Loyalty Ridge and basin system, Southwest Pacific (first results of the ZoNéCo programme)
}

Yves Lafoy, François Missegue, Dominique Cluzel, Raymond Le Suavé

\section{- To cite this version:}

Yves Lafoy, François Missegue, Dominique Cluzel, Raymond Le Suavé. The Loyalty-New Hebrides Arc collision: Effects on the Loyalty Ridge and basin system, Southwest Pacific (first results of the ZoNéCo programme). Marine Geophysical Research, 1996, 18, pp.337-356. 10.1007/BF00286084 . hal-00122516

\section{HAL Id: hal-00122516 \\ https://hal-insu.archives-ouvertes.fr/hal-00122516}

Submitted on 3 Jan 2007

HAL is a multi-disciplinary open access archive for the deposit and dissemination of scientific research documents, whether they are published or not. The documents may come from teaching and research institutions in France or abroad, or from public or private research centers.
L'archive ouverte pluridisciplinaire HAL, est destinée au dépôt et à la diffusion de documents scientifiques de niveau recherche, publiés ou non, émanant des établissements d'enseignement et de recherche français ou étrangers, des laboratoires publics ou privés. 


\title{
The Loyalty-New Hebrides Arc Collision: Effects on the Loyalty Ridge and Basin System, Southwest Pacific (First Results of the ZoNéCo Programme)
}

\author{
YVES LAFOY ${ }^{1}$, FRANCOIS MISSEGUE ${ }^{2}$, DOMINIQUE CLUZEL ${ }^{3}$ and RAYMOND LE SUAVE ${ }^{4}$ \\ ' Service des Mines et de l' Energie, BP 465, 98845 Nouméa cedex, Nouvelle-Calédonie \\ ${ }^{2}$ Laboratoire de Géologie-Géophysiqüe, Cèntre Orstom de Nouméa, BP A5, UR 14, 98848 Nouméa cedex, Nouvelle-Calédonie \\ ${ }^{3}$ Université Française du Pacifique, CUNC, B.P. 4777, Nouméa, Nouvelle-Calédonie \\ ${ }^{4}$ Ifremer/CB, BP 70, 29280 Plouzané, France
}

(Received 21 March 1995; accepted 18 August 1995)

Key words: Southwest Pacific, Loyälty Basin, Loyalty Ridge, New . Hebrides Arc collision, strike-slip tectonics

\begin{abstract}
The ZoNéCo 1 and 2 cruises of Ifremer's Research Vessel L'Atalante, collected new swath bathymetry and geophysical data over the southern and northern segments of the basins and ridges forming the Loyalty system. Between the two surveyed areas, previous studies found evidence for the resistance of the Loyalty Ridge to subduction beneath the New Hebrides trench near $22^{\circ} \mathrm{S}-169^{\circ} \mathrm{E}$. On the subducted plate, except for seismicity related to the downbending of the Australian plate, recorded shallow seismicity is sparse within the Loyalty system (Ridge and Basin) where reliable focal mechanism solutions are almost absent.

Swath bathymetry, seismic reflection and magnetic data acquired during the ZoNéCo 1 and 2 cruises revealed a transverse asymmetric morphology in the Loyalty system, and an along-strike horst and graben structure on the discontinuous Loyalty Ridge. South of $23^{\circ} 50^{\prime} \mathrm{S}$ and at $20^{\circ} \mathrm{S}$, the two WSW-ENE-trending fault systems, respectively, sinistral and dextral, that crosscut the southern and northern segments of the Loyalty system, are interpreted as due to the early effects of collision with the New Hebrides Arc. A NNWSSE trend, evident along the whole Loyalty system and on the island of New Caledonia, is interpreted as an inherited structural trend that may have been reactivated through flexure of the Australian lithospheric plate at the subduction zone.

Overall then, the morphology, structure and evolution of the southern and northern segments of the Loyalty system probably result from the combined effects of the Australian plate lithospheric bulge, the active Loyalty-New Hebrides collision and the overthrust of the New Caledonian ophiolite.
\end{abstract}

\section{Introduction}

The overall structure of the Southwest Pacific region can be summarised as resulting from successive openings of marginal basins that isolated ridges of either continental, oceanic or intermediate nature since the late Cretaceous.

Marine Geophysical Researches 18: 337-356, 1996.

(C) 1996 Kluwer Academic Publishers. Printed in the Netherlands.
The Southwest Pacific region in the area of study is dominated by the subduction of the Australian plate beneath the New Hebrides Arc at a rate of $12 \mathrm{~cm} / \mathrm{y}$, with a direction of convergence that trends WSWENE (Dubois et al., 1977) (Figure 1). The subduction causes collision between the Loyalty Ridge and the New Hebrides Arc. West of the collision zone, three parallel geological units that trend NW-SE north of $22^{\circ} 30^{\prime} \mathrm{S}$ and N-S south of this latitude are present from east to west (Figure 1):

1. The South-Fiji and North-Loyalty basins flank the Loyalty Ridge to the southeast and to the northwest respectively, except near $22^{\circ} \mathrm{S}-169^{\circ} \mathrm{E}$ where the Loyalty Ridge collides with the southern New Hebrides Arc (Monzier et al:, 1990). The New Hebrides Arc has been active since the late Miocene (MacFarlane et al., 1988). The South-Fiji Basin probably represents the southeastern extension of the NorthLoyalty Basin (Collot et al., 1985).

2. The 1,000 km-long, $25 \mathrm{~km}$-thick (Collot et al., 1982) Loyalty Ridge that bounds the Loyalty'Basin to the east, is made up of Oligocene (34-26 Ma) submarine alkaline volcanic rocks (Monzier, 1993), and of alkaline basalts dated 9-11 Ma (Baubron et al., 1976) that outcrop on Maré Island. During the Pleistocene, the lithospheric swell on the subducted Australian plate caused the uplift of the Loyalty Ridge (Dubois et al., 1974). In the vicinity of the Loyalty Ridge - New Hebrides Arc collision zone, sparse shallow seismicity on the subducting Australian plate reveals the activity of normal faults north and south of $22^{\circ} \mathrm{S}$ (Monzier, 1993). However, this author provided evidence for a W-E sinistral offset of the magnetic lineations of the Loyalty Ridge near $21^{\circ} 55^{\prime} \mathrm{S}$. The sole known

$\Leftrightarrow$

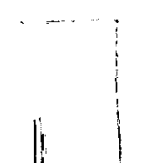

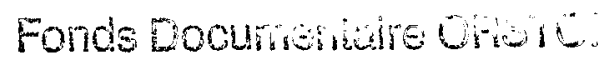

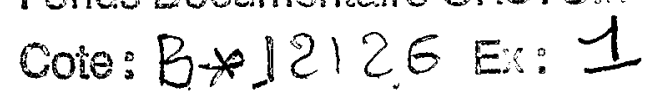




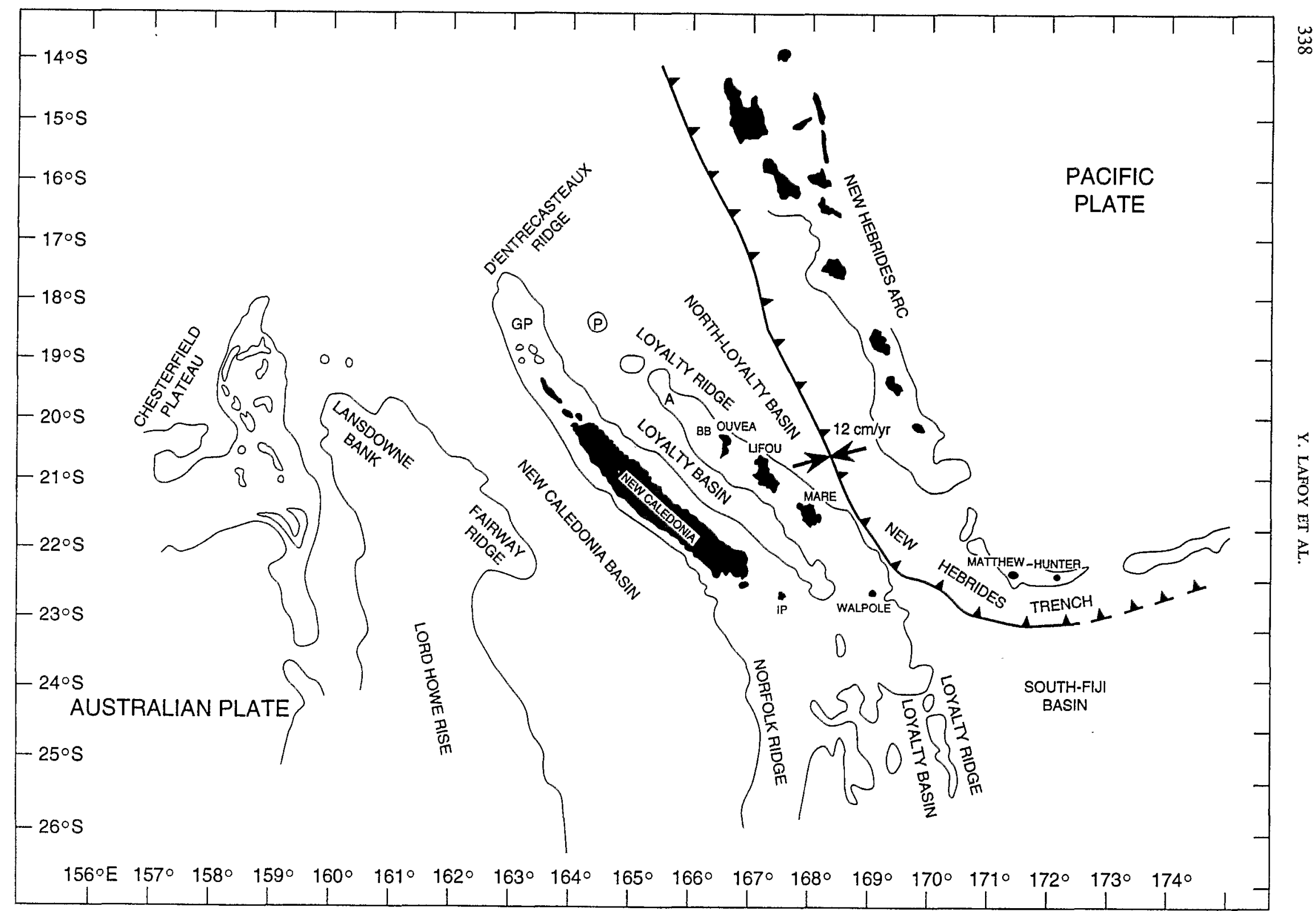

Fig. 1. Main structural features around New Caledonia. Bathymetry: $2,000 \mathrm{~m}$ isobath. $12 \mathrm{~cm} / \mathrm{y}$ : Australian-Pacific plate convergence rate. GP: Grand Passage; P: Pétrie Reef; A: Astrolabe Reef; BB: Beautemps-Beaupré Atoll; IP: "Tle des Pins". 
THE LOYALTY-NEW HEBRIDES ARC COLLISION

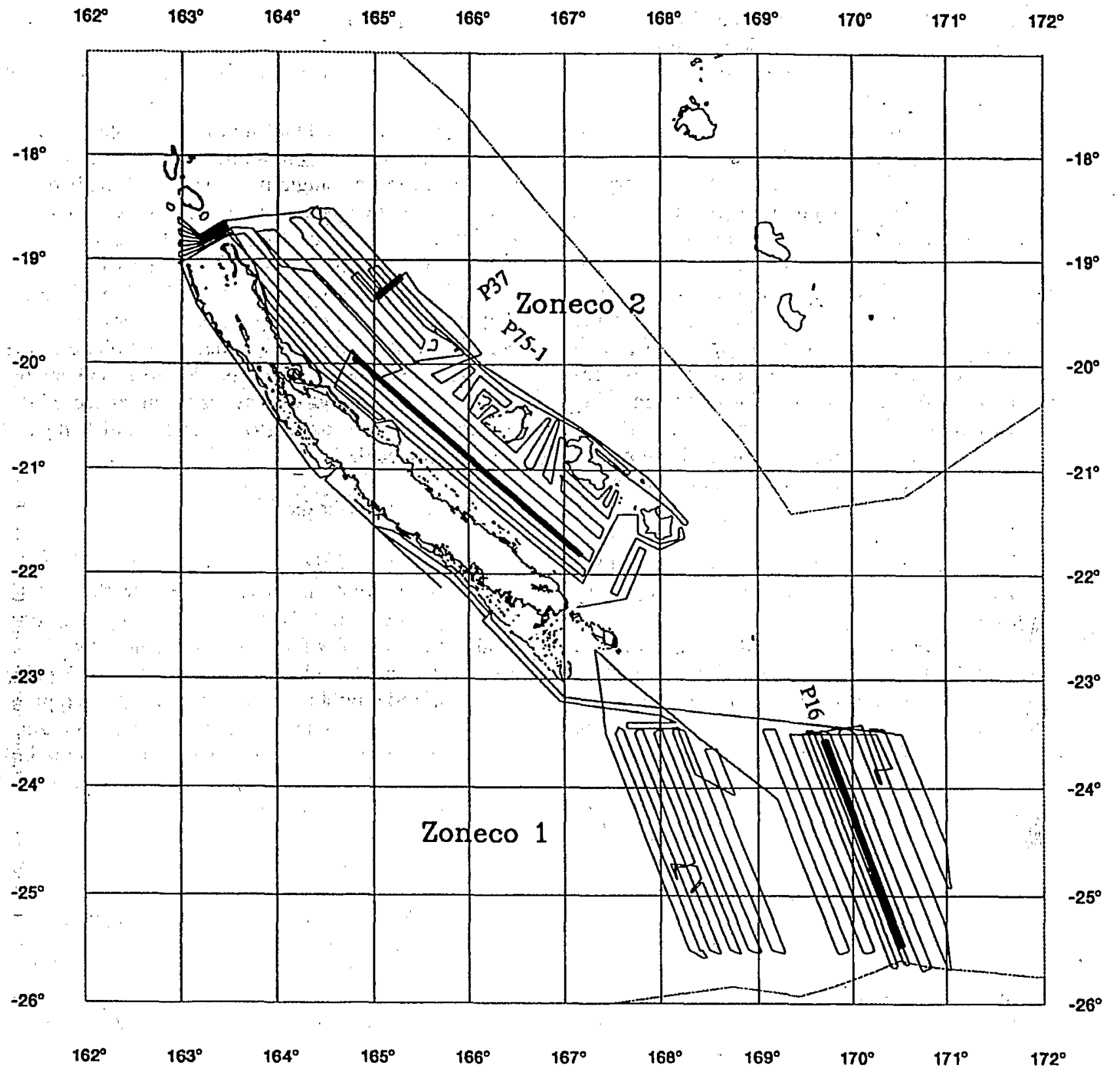

Fig. 2. Tracklines of the ZoNéCo 1 (Southern Box) and ZoNéCo 2 (Northern Box) cruises. Thick lines: location of seismic lines with, from south to north: ZoNéCo 1 NNW-SSE-trending line P16 (Figure 5), ZoNéCo 2 NW-SE-trending line P75-1 (Figure 10), and ZoNéCo 2 WSW-ENE-trending line P37 (Figure 9).

strike-slip focal mechanism on the Australian plate lies near $21^{\circ} 30^{\prime} \mathrm{S}$, east of Maré Island, and shows a dextral component (Monzier, 1993). On the overriding Pacific plate, between $21^{\circ} 50^{\prime} \mathrm{S}$ and $22^{\circ} 10^{\prime} \mathrm{S}$, the author reports a group of earthquakes with W-E sinistral strike-slip focal mechanisms. The origin of the Loyalty Ridge is still much debated
(Kroenke, 1984; Monzier, 1993; Dupont et al., 1995).

3. The Loyalty Basin, bounded by the Loyalty and the Norfolk/New Caledonia ridges, is 2,000 m deep in average. Numerous data on the Loyalty Basin were obtained during reconnaissance expeditions of petroleum exploration nature such as Gulf 
(1972), Mobil Oil (1972), Austradec I (1972), and during scientific cruises Nova (Scripps Institution, 1965-67), Kimbla and Coriolis (1970-71), Georstom I and II (1973-1974), and Eva I, II, VI and VII (1976-78). In spite of the amount of data collected, a few publications have presented in an exhaustive way the structure and the history of the Loyalty Basin and its margin (Bitoun et Récy, 1982; Pontoise et al., 1982; Collot et al., 1982; Ravenne et al., 1982). Seismic reflection and refraction data indicated that the structure of the Loyalty Basin was established after the obduction, in the upper Eocene, of the ophiolite nappe on the Norfolk/New Caledonia Ridge. Originally, the ophiolite nappe and the substratum of the basin, a 17 $\mathrm{km}$-thick (Collot et al., 1982) Eocene oceanic crust (Weissel et al., 1977) were continuous. The Loyalty Basin is filled by post-Oligocene sediments (Ravenne et al., 1982). Bitoun et Récy (1982), identified from seismic reflection data, WSW-ENEtrending rises of the acoustic basement that they interpret as aseismic fracture zones that crosscut the Loyalty Basin and Ridge.

4. The Norfolk/New Caledonia Ridge, that connects to the south with the New Zealand North island. The N150 E northern segment of the ridge, or New Caledonia Ridge, was overthrusted in the late Eocene by the Caledonian ophiolites (Paris, 1981), and was then affected by a late Pliocene subsidence phase (Daniel et al., 1976). During the late Miocene-Pliocene, a general uplift phase affected the New Caledonia region (Paris, 1981). Alkaline basaltic volcanism affected the eastern flank of the Norfolk Ridge 20 my ago (Daniel et al., 1976).

New bathymetric and geophysical data were collected during the ZoNéCo 1 (26 June-15 July, 1993) and ZoNéCo 2 (02-22 August, 1994) cruises aboard $\mathrm{R} / \mathrm{V}$ L'Atalante. Equipped with the EM 12 Dual multibeam system, seismic reflection, magnetic and gravimetric equipment, L'Atalante performed two swath bathymetric and geophysical surveys, southeast and northwest of the Loyalty-New Hebrides collision zone between $23^{\circ} 30^{\prime} \mathrm{S}-25^{\circ} 30^{\prime} \mathrm{S}$ and $167^{\circ} 20^{\prime} \mathrm{E}-171^{\circ} \mathrm{E}$, and $18^{\circ} 30^{\prime} \mathrm{S}-22^{\circ} 15^{\prime} \mathrm{S}$ and $162^{\circ} 50^{\prime} \mathrm{E}-168^{\circ} 20^{\prime} \mathrm{E}$, respectively (Figure 2). This set of new data supports a detailed morphostructural study of the southern and northern segments of the Loyalty system, the Loyalty system being made of the Loyalty Basin and the Loyalty Ridge. A new interpretation in terms of active collision between the Loyalty Ridge and the New Hebrides Arc is proposed.

\section{Data Acquisition}

\subsection{MULTiBEAm BATHYMETRY AND ACOUSTIC IMAGERY}

The Simrad EM 12 Dual multibeam system aboard $\mathrm{R} / \mathrm{V}$ L'Atalante allows a swath up to $20 \mathrm{~km}$-wide to be mapped in one single pass, with both bathymetry and side-scan imagery. The EM 12 Dual system operates at a frequency of $13 \mathrm{kHz}$, and consists of two separate multibeam echosounders (one to port and one to starboard), each generating 81 stabilised beams that provide a coverage up to seven times the water depth. The determination of energy and phase of the backscattered signal provides detailed bathymetry within the swath and displays a sonar image of the seabed reflectivity, both geometrically and bathymetrically corrected.

\subsection{SeISMiC REFLECTION}

A six-channel seismic system was used, with 2 GI airgun sources that do not interfere with the EM 12 Dual echo sounder. This system allows a penetration of about $2.5 \mathrm{sec}$. TWT through sediments, when it is used at 10 knots. Sodera GI guns comprise a pulse generator and a bubble suppressor that fully suppress the oscillations of each individual bubble. The GI guns preserve the primary pressure pulse while eliminating the secondary pulse through precise tuning of an air injection within the bubble.

\subsection{MAGNeTiCS}

Magnetic data were acquired at a $6 \mathrm{sec}$ sampling interval using a Barringer M-244 proton magnetometer, towed 280 meters astern the ship. Magnetic anomalies were computed by subtracting the IGRF 90 from the measured total field, but not corrected for diurnal variations. As the accuracy of the magnetometer is equal to about $0.5 \mathrm{nT}$, cross-over errors are mainly due to diurnal variations.

\section{Results of the ZoNéCo 1 and ZoNéCo 2 Cruises}

\subsection{ThE SOUTHERN BOX: ZoNéCo 1}

\subsubsection{Bathymetric Data}

From west to east, the bathymetric map of the ZoNéCo 1 cruise, that surveyed the southern part of the Loyalty system (Basin and Ridge), shows (Figure 3):

1. The submerged part of the New Caledonia basement, that is represented by the $\mathrm{N} 160^{\circ}$ E-trending. 


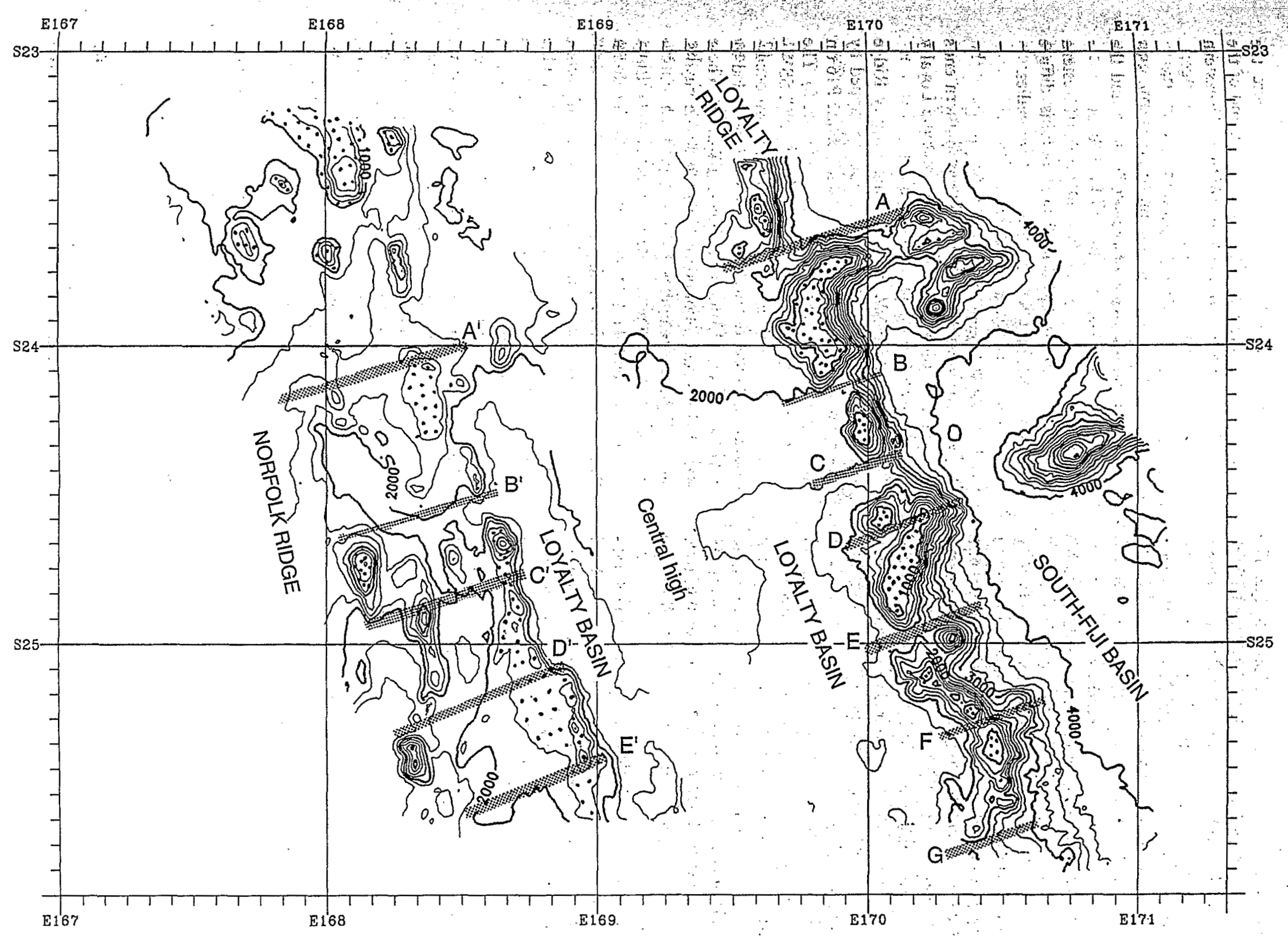

Fig. 3. Bathymetric map of the Southern Box (ZoNéCo 1 cruise). Mercator projection WGS84, contour interval: 250 m; . Dotted areas: Guyots; Shaded lines A to G and A' to E': lineaments across the Loyalty Ridge and the Norfolk / Now Caledonia Ridge, respectively.

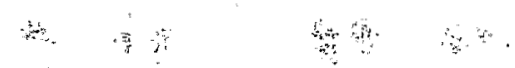


1000 m-deep Norfolk/New Caledonia Ridge. The ridge is composed of a shallow $(1,000$ to $1,500 \mathrm{~m}$ deep) plateau dotted with seamounts that culminate at $200 \mathrm{~m}$. The plateau deepens to the south to reach $2,000 \mathrm{~m}$ depth. South of $24^{\circ} 10^{\prime} \mathrm{S}$, the plateau has the form of a series of elongated and sigmoidal volcanic ridges that trend NNW-SSE, N-S and SSW-NNE. South of $24^{\circ} \mathrm{S}$, these ridges are crosscut by WSW-ENE-trending lineaments $\left(A^{\prime}\right.$ to $\left.E^{\prime}\right)$ (Figure 3).

2. The $\mathrm{N} 160^{\circ}$ E-trending southern part of the Loyalty Basin, 2,000 to 2,500 $\mathrm{m}$ deep, is characterised by a smooth topography. The Loyalty Basin deepens and widens southward, south of the WSW-ENE-trending lineament B centred at $24^{\circ} 10^{\prime} \mathrm{S}$. South of this transverse lineament, the basin splits into two 2,500 m-deep, NNW-SSE depressions located west and east of a parallel central high threshold that ends south of $25^{\circ} 10^{\prime} \mathrm{S}$.

3. The $\mathrm{N} 160^{\circ}$ E-trending Loyalty Ridge is made of elongated and tabular structures or guyots that culminate at $1,000 \mathrm{~m}$, and of seamounts that locally cap the guyots. The ridge is discontinuous, being made of segments that trend SSW-NNE, NNW-SSE, WSW-ENE. It is crosscut south of $23^{\circ} 35^{\prime} \mathrm{S}$, by WSW-ENE lineaments (A to $\mathrm{G}$ ) (Figure 3).

4. To the east, the northwestern corner of the SouthFiji Basin is characterised by a water depth of $4,000 \mathrm{~m}$. At $23^{\circ} 40^{\prime} \mathrm{S}$ and $24^{\circ} 20^{\prime} \mathrm{S}$ in the basin there are two WSW-ENE volcanic features that culminate at $1,000 \mathrm{~m}$.

\subsubsection{Magnetic Data}

'The magnetic anomaly map of the Southern Box confirms the main structures and trends that characterise the southern parts of the Norfolk/New Caledonia Ridge and the Loyalty system in the study area (Figure 4):

1. To the west, the submerged part of the Norfolk/New Caledonia basement is characterised by $\mathrm{N} 170^{\circ} \mathrm{E}$ to $\mathrm{N}-\mathrm{S}$ elongated magnetic anomalies, with peak to peak values in the range of +200 to $+300 \mathrm{nT}$.

2. The Loyalty system is characterised by NNW-SSE magnetic anomalies. The magnetic pattern of the Loyalty Basin comprises a series of parallel magnetic highs and lows that range between -200 and $+200 \mathrm{nT}$. The magnetic signature of the Loyalty Ridge shows highs that reach a maximum of $+400 \mathrm{nT}$. These NNW-SSE-trending magnetic highs are sinistrally offset along the ridge by WSWENE to W-E-trending faults. To the west, the WSW-ENE faults extend:
- from $25^{\circ} \mathrm{S}-168^{\circ} \mathrm{E}$ to $24^{\circ} \mathrm{S}-170^{\circ} \mathrm{E}$, where the transverse fault delimits the northern end of the Loyalty Basin central high and offsets the eastern margin of the Norfolk/New Caledonia Ridge;

- from $25^{\circ} 50^{\prime} \mathrm{S}-169^{\circ} \mathrm{E}$ to $25^{\circ} 10^{\prime} \mathrm{S}-170^{\circ} 30^{\prime} \mathrm{E}$, where the transverse fault offsets the NNW-SSE magnetic lineations of the central high and the eastern depression of the Loyalty Basin.

3. To the east, the western edge of the northwestern corner of the South-Fiji Basin contains diffuse WSW-ENE and NW-SE magnetic anomalies.

\subsubsection{Seismic Reflection Data}

Seismic reflection data reveal that the southern ends of both the Norfolk/New Caledonia and the Loyalty ridges are made of guyots and seamounts.

The generally NNW-SSE-trending Loyalty Ridge is made of a succession of guyots locally capped by uneroded seamounts, as shown on seismic line P16 on the eastern flank of the Loyalty Ridge (Figure 5). The guyots of the Loyalty Ridge trend NNW-SSE, SSWNNE and NW-SE, their changes of direction occurring within WSW-ENE-trending grabens bounded by normal faults that delimit the guyots (Figure 5). These fault sets (A to F) bound the Loyalty Ridge guyots, suggesting that the graben areas may represent potential weak zones that have underwent recurrent faulting.

On the eastern flank of the Norfolk/New Caledonia Ridge, WSW-ENE-trending lineaments $\mathrm{B}^{\prime}, \mathrm{C}^{\prime}$ and $\mathrm{D}^{\prime}$ are interpreted as strike-slip faults that sinistrally offset both the western Loyalty Basin and the eastern edge of the Norfolk/New Caledonia Ridge. The latter is dominated south of $24^{\circ} \mathrm{S}$ by elongated and sigmoïdal volcanic ridges made of seamounts.

Our interpretation of the seismic reflection data, coupled with petrological data (Daniel et al., 1976; Monzier, 1993), and the chronology of vertical movements that affected the region (Paris, 1981), enable us to associate the two types of volcanic structures (i.e. guyots and seamounts), with two distinct volcanic phases. The first volcanic phase, that created the guyots of the Norfolk/New Caledonia and Loyalty ridges, probably corresponds to the submarine alkaline phase dated Oligocene-early Miocene by Daniel et al. (1976) and Monzier (1993). The alkaline volcanic substratum might have become emergent during regional late Miocene-Pliocene uplift (Paris, 1981). The guyots that resulted from this uplift might then have subsided during late Pliocene regional subsidence (Daniel et al., 1976). The second volcanic phase, that gave rise to the uneroded seamounts, likely post-dated the late Miocene-Pliocene general uplift phase (Paris, 1981). 


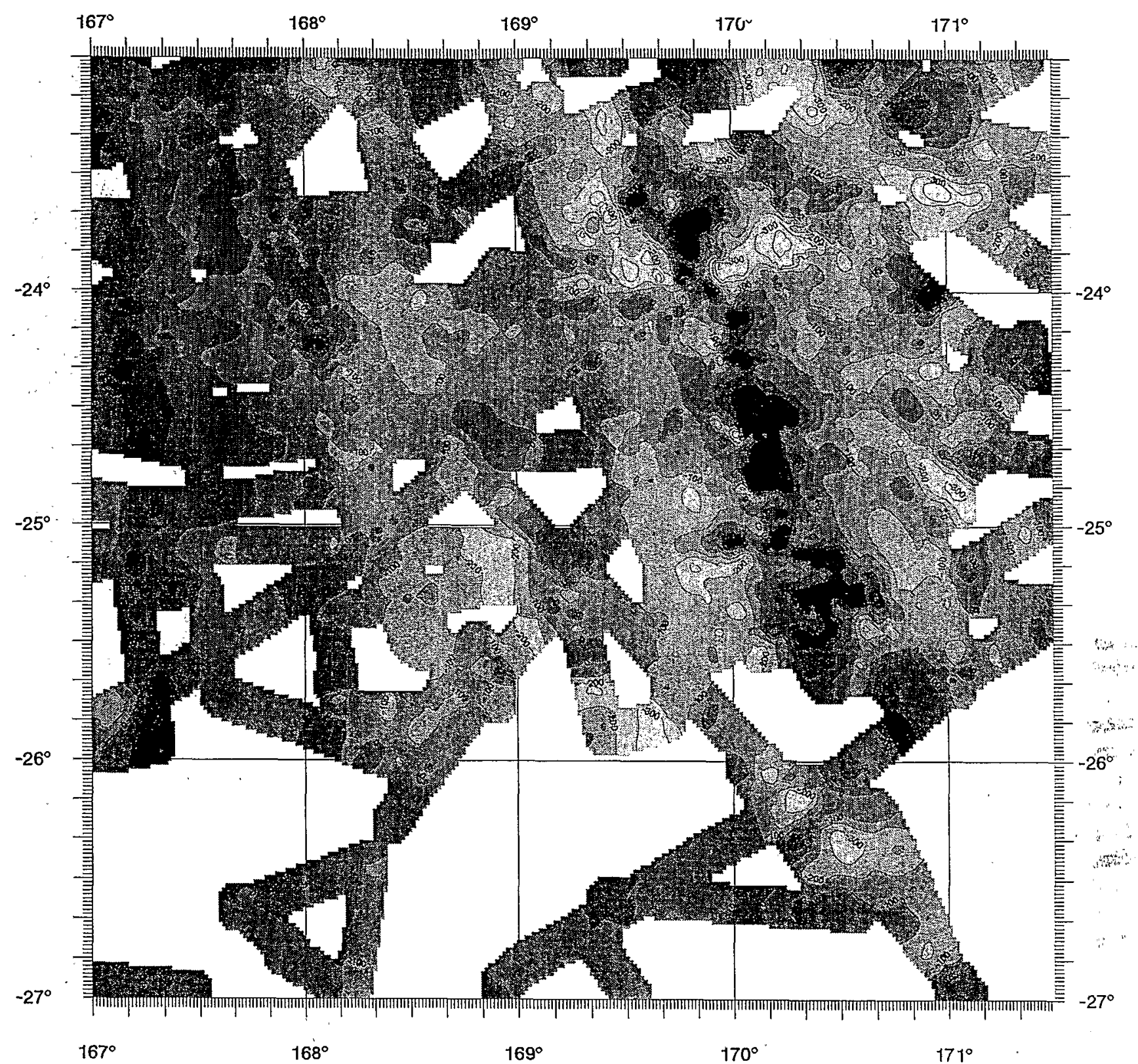

Fig. 4. Magnetic anomaly map of the Southern Box (ZoNéCo 1 cruise). Mercator projection WGS84, iso-anomalies are contoured at $100 \mathrm{nT}$ intervals.

\subsubsection{Interpretation of the Structural Map}

The structural map that results from the interpretation of seismic reflection and magnetic data (Figure 6), reveals that WSW-ENE-trending strike slip faults sinistrally offset both the Loyalty system, and the Norfolk/New Caledonia Ridge.

The structural map allows to define the relative ages of the fault sets:
1. A NNW-SSE trend corresponds to the main structural direction, as it parallels the Loyalty system basins and ridges and the eastern edge of the Norfolk/New Caledonia Ridge. Within the Loyalty Basin, the two NNW-SSE depressions and the central high are bounded by parallel normal faults. This NNW-SSE trend is increasingly disturbed toward the east, along the faulted Loyalty Ridge. 


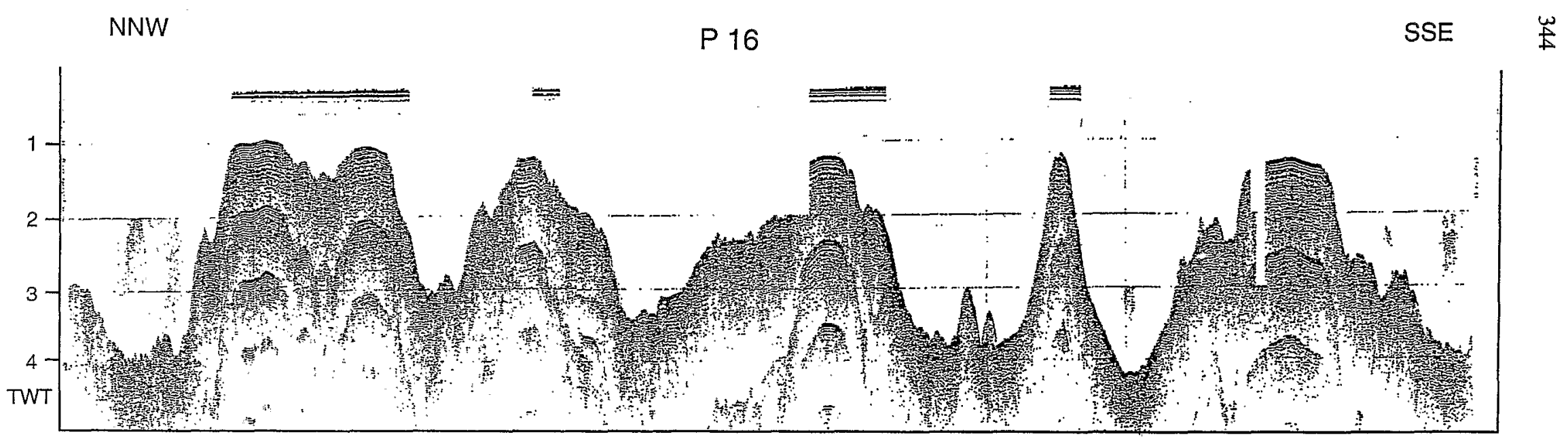

NNW

P 16

5
5
2
3
3
3
3

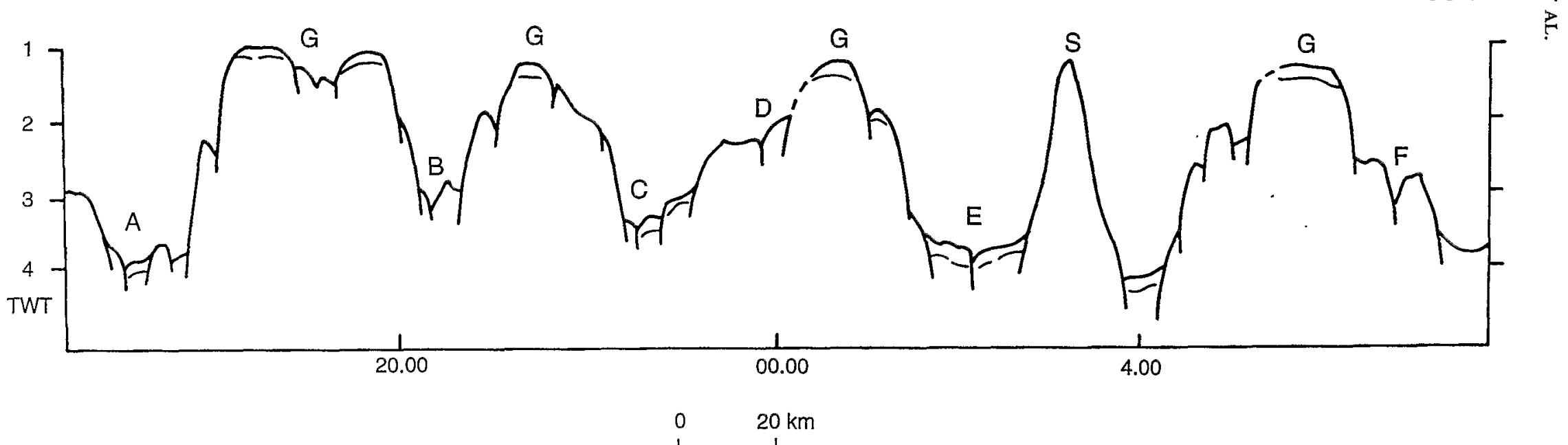

Fig. 5. ZoNéCo 1 seismic line P16 on the Loyalty Ridge. For location, see Figure 2. Vertical Exaggeration: 30; Vertical scale: Sec Two-Way-Time; G: Guyot; S: Seamount; A to F: faults within grabens. 
Grabens along the ridge were probably tectonically reactivated through recent strike-slip faulting.

2. A WSW-ENE trend is expressed through a transverse strike-slip system that offsets the Loyalty Ridge guyots and extends westwards, deepening through the Loyalty Basin and the eastern edge of the Norfolk/New Caledonia Ridge.

3. A SSW-NNE trend occurs on the Norfolk/New Caledonia Ridge and its elongated volcanic ridges bounded by normal faults south of the $24^{\circ} 30^{\prime} \mathrm{S}$ WSW-ENE lineament $B^{\prime}$. On the Loyalty Ridge, the SSW-NNE trend is evident through either eastward-dipping normal faults or through local dextral strike-slip faults.

\subsection{THE NORTHERN BOX: ZoNéCo 2}

\subsubsection{Bathymetric Data}

From west to east, the bathymetric map of the ZoNéCo 2 cruise, that surveyed the northern part of the Loyalty system (Basin and Ridge), reveals the morphology of both the eastern margin of New Caledonia and the Loyalty system (Figure 7). Three main units can be defined from west to east:

1. The eastern margin of New Caledonia, characterised by a pronounced change in morphology, north and south of a bathymetric high centred at $20^{\circ} 40^{\prime} \mathrm{S}$. North of $20^{\circ} 40^{\prime} \mathrm{S}$, the margin is a broad seaward-concave curve cut by canyons, whereas south of this latitude, the margin is rectilinear and steep and devoid of canyons.

2. The Loyalty Basin, characterised by a general NW-SE trend and a flat floor. The basin deepens to the north and can be divided north and south of $20^{\circ} 40^{\prime} \mathrm{S}$, into:

- a northern $\mathrm{N} 135^{\circ} \mathrm{E}$ part, $75 \mathrm{~km}$-wide, that deepens from $2,500 \mathrm{~m}$ near $20^{\circ} 20^{\prime} \mathrm{S}$, to $3,800 \mathrm{~m}$ at $18^{\circ} 40^{\prime} \mathrm{S}$. The basin is asymmetric, with its deepest part lying along the western edge of the Loyalty Ridge. The western side of the basin is dotted with volcanoes at $19^{\circ} \mathrm{S}$ and $19^{\circ} 55^{\prime} \mathrm{S}$ and with $\mathrm{N} 135^{\circ} \mathrm{E}$-trending small ridges at $18^{\circ} 50^{\prime} \mathrm{S}$ and $20^{\circ} 05^{\prime} \mathrm{S}$;

- a flat-and-smooth $\mathrm{N} 125^{\circ} \mathrm{E}$-trending southern part, $45 \mathrm{~km}$-wide and 2,200 m-deep, that slightly dips to the SW.

The Loyalty Basin abruptly deepens to the north, north of the $20^{\circ} 40^{\prime} \mathrm{S}$ high that is cut to the southeast by the NNW-SSE-trending, northwardflowing channel centred at $20^{\circ} 20^{\prime} \mathrm{S}$.

3. The Loyalty Ridge, that trends NW-SE, and its northward submarine extension defined by Beautemps-Beaupré Atoll and by the Astrolabe and Pétrie reefs (Figure 7) are made of guyots and seamounts. The Loyalty Ridge can be divided, north and south of $20^{\circ} 10^{\prime} \mathrm{S}$, into a $\mathrm{N} 135^{\circ} \mathrm{E}$-trending segment and a $\mathrm{N} 125^{\circ} \mathrm{E}$-trending segment, respectively.

\subsubsection{Magnetic Data}

The magnetic anomaly map of the Northern Box confirms the main structures and trends that characterise the northern part of the Loyalty system. From east to west (Figure 8):

1. The Loyalty Ridge and its eastern edge are characterised by high magnetic values. They reach +500 $\mathrm{nT}$ on and east of the Loyalty Islands, and decrease to the north with average values of $+300 \mathrm{nT}$ on Astrolabe and Pétrie reefs. At $20^{\circ} \mathrm{S}$, the overall positive magnetic anomaly signature of the ridge is crosscut by a W-E-trending negative lineation. At this latitude, the positive signature of the Loyalty Ridge that changes direction from $\mathrm{N} 135^{\circ} \mathrm{E}$ north of $20^{\circ} \mathrm{S}$ to $\mathrm{N} 125^{\circ} \mathrm{E}$ south of this latitude, is slightly dextrally offset.

2. The northern part of the Loyalty Basin, north of $20^{\circ} \mathrm{S}$, characterised by $\mathrm{N} 135^{\circ} \mathrm{E}$-trending lineations, is dominated on its eastern side by a magnetic low that occurs with a minimum of $-400 \mathrm{nT}$ at $20^{\circ} \mathrm{S}$. This $\mathrm{N} 135^{\circ} \mathrm{E}$-trending magnetic low, that represents the overall signature of the Loyalty Basin northern part, lies along the western side of the Loyalty Ridge. At $20^{\circ} \mathrm{S}$, this lineation bends to the east where it trends WNW-ESE to W-E, and crosscuts the Loyalty Ridge. At the western side of the basin a NNW-SSE-trending magnetic high reaches a maximum of $+100 \mathrm{nT}$.

3. Between $20^{\circ} \mathrm{S}$ and $20^{\circ} 40^{\prime} \mathrm{S}$, the central part of the Loyalty Basin is characterised by transverse lineations that mainly trend WNW-ESE. The $\mathrm{N} 125^{\circ} \mathrm{E}$-trending magnetic low that occurs with a minimum of $-200 \mathrm{nT}$ at $20^{\circ} 20^{\prime} \mathrm{S}, 165^{\circ} 30^{\prime} \mathrm{E}$, represents the signature of the basin, this signature disappearing southward. The $\mathrm{N} 125^{\circ} \mathrm{E}$-trending low is dextrally offset from the $\mathrm{N} 135^{\circ} \mathrm{E}$-trending, $-400 \mathrm{nT}$ magnetic low of the northern part of the basin. The dextral offset between the $\mathrm{N} 135^{\circ} \mathrm{E}$ and $\mathrm{N} 125^{\circ}$ E-trending magnetic lows north and south of $20^{\circ} \mathrm{S}$, is confirmed by the sigmoïdal geometry of the lineations, respectively curved eastward and westward.

4. The southern part of the Loyalty Basin, south of $20^{\circ} 40^{\prime} \mathrm{S}$, characterised by $\mathrm{N} 125^{\circ} \mathrm{E}$ to $\mathrm{N} 130^{\circ} \mathrm{E}$ lineations, is dominated on its eastern side by a $\mathrm{N} 125^{\circ} \mathrm{E}$ magnetic low. This negative lineation that occurs with a minimum of $-400 \mathrm{nT}$ and extends from $21^{\circ} 40^{\prime} \mathrm{S}$ south of Lifou Island to $20^{\circ} 40^{\prime} \mathrm{S}$ 


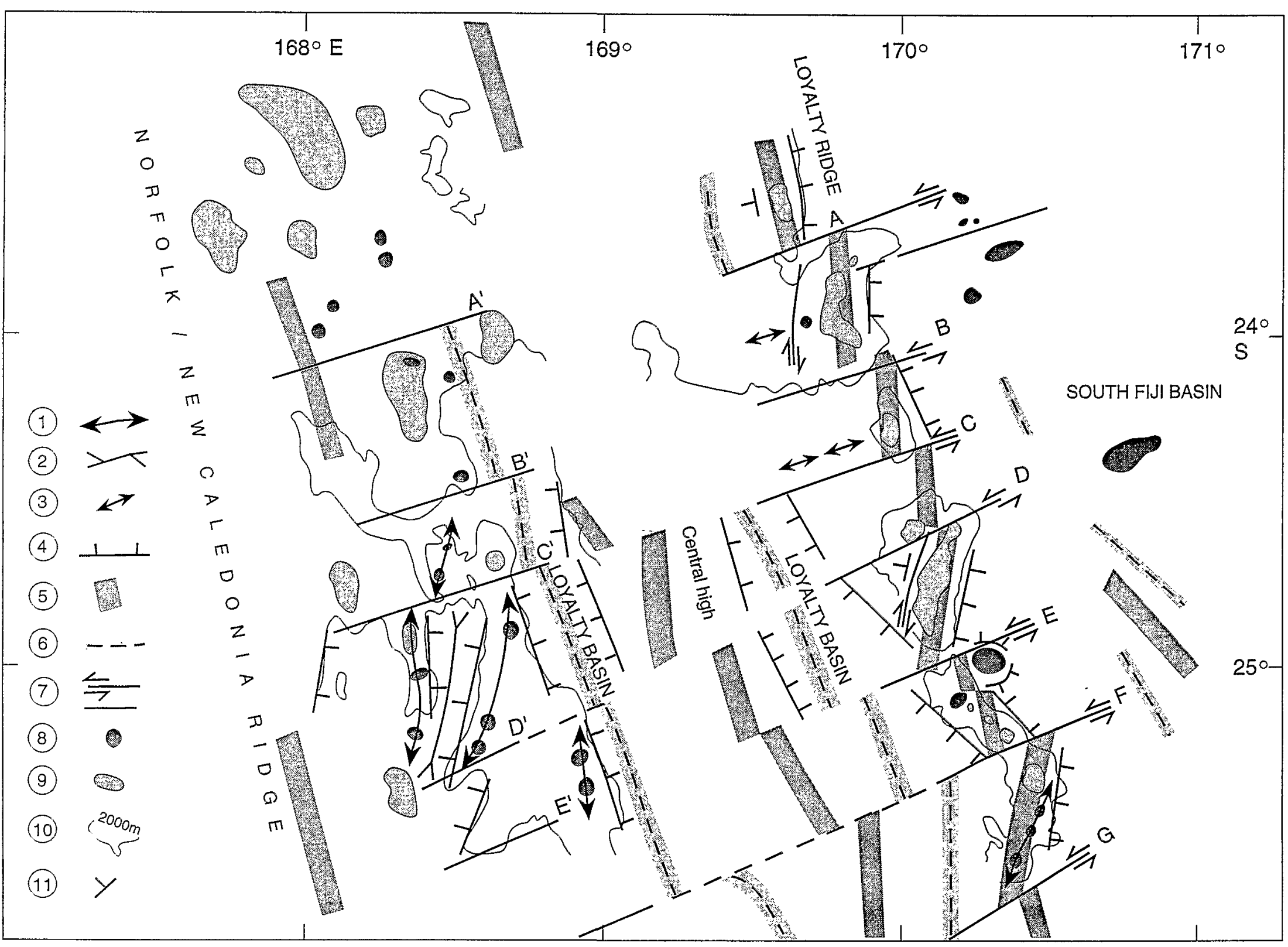

Fig. 6. Structural map of the Southern Box. 1: ridges; 2: depressions; 3: buried highs; 4: normal faults; 5: positive magnetic lineation; 6: negative magnetic lineation; 7: strike slip/ vertical-throw faults: 8 : seamounts: 9: guvnts: $10: 2.000 \mathrm{~m}$ isobath: 11: structures' din. 

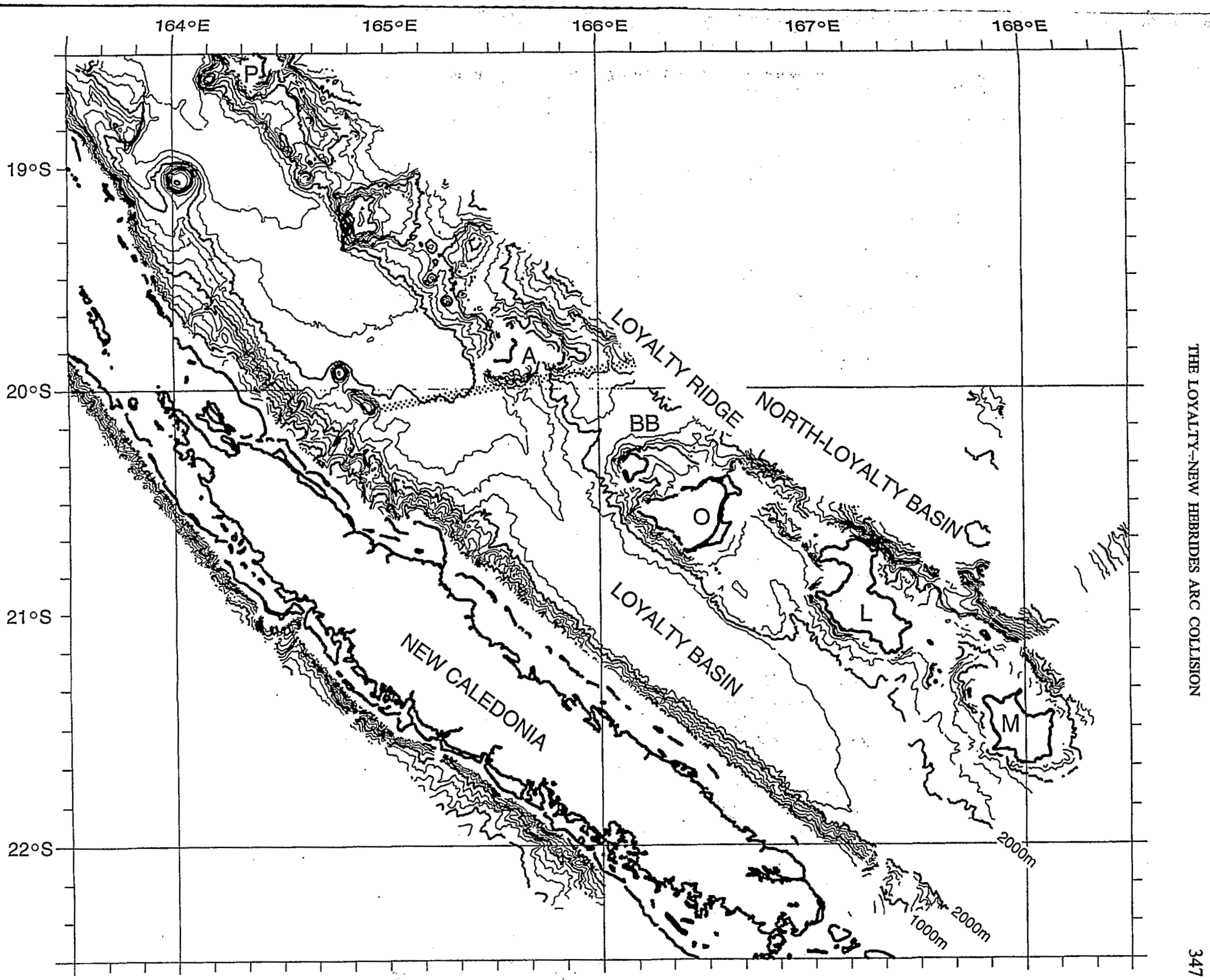

Fig. 7. Bathymetric map of the Northern Box (ZoNéCo 2 cruise). Mercator projection WGS84, contour interval: $250 \mathrm{~m}$; Shaded line: lineament; P: Pétrie Reef; A: Astrolabe Reef; BB Beautemps-Beaupré Atoll; O, L, M: Ouvéa, Lifou, Maré islands. 
where it bends to the west, represents the signature of the southern part of the basin. To the southwest, a $\mathrm{N} 130^{\circ} \mathrm{E}$ magnetic high that reaches a maximum of $+300 \mathrm{nT}$ near $21^{\circ} 30^{\prime} \mathrm{S}$ underlines the western edge of the southern part of the basin.

\subsubsection{Seismic Reflection Data}

Seismic reflection data reveal the asymmetric morphology and structure of the Loyalty system.

The Loyalty Ridge and its submarine northern extension can be divided, north and south of $20^{\circ} 10^{\prime} \mathrm{S}$, into:

- a N $135^{\circ}$ E-trending northern segment, made up of NNW-SSE-trending guyots that culminate at 800 $\mathrm{m}$. They are bounded north and south by WSWENE faults, and west and east by NNW-SSE and NW-SE-trending normal faults, respectively. The NNW-SSE-trending highs are tilted toward the east, as shown on seismic line P37 that crosses the eastern flank of the Loyalty Ridge (Figure 9). All along the Loyalty Ridge, the guyots and their bounding faults reflect a horst and graben structure;

- a N $125^{\circ}$ E-trending southern segment, bounded west and east by NNW-SSE and NW-SE-trending scarps, respectively. Between the outcropping islands, like in the northern segment, the main structural features trend NNW-SSE and are locally offset by WSW-ENE-trending faults.

Within the Loyalty Basin, the seismic data reveal the difference of structure of the basin north and south of the northeastward-deepening extension of the $20^{\circ} 40^{\prime}$ S high. Seismic line P75-1 shows the along-strike structure of the Loyalty Basin (Figure 10). The $2200 \mathrm{~m}$ deep, $\mathrm{N} 125^{\circ} \mathrm{E}$-trending southern part of the basin is filled by sediments that reach a maximum thickness of $2.5 \mathrm{sec}$. TWT, whereas in its deeper ( 3000 to $3700 \mathrm{~m}$ ) northward-dipping $\mathrm{N} 135^{\circ}$ E-trending northern part, the sedimentary filling is less than $2 \mathrm{sec}$. TWT (Figure 10). The structural $20^{\circ} 40^{\prime} \mathrm{S}, \mathrm{SW}-\mathrm{NE}$-trending high is bounded to the north by a WNW-ESE scarp that delimits the deep, faulted central part of the Loyalty system, and to the south, by a NNW-SSE scarp. South and north of the $20^{\circ} 40^{\prime} \mathrm{S}$ high, five main acoustic basement upraises occur (Figure 10). The southern upraises ( $Y$, underlain to the channel in the Loyalty Basin west of Ouvéa, and southeast of fault $Z$ on Figures 10 and 11) trend NNW-SSE. To the north, acoustic high $U$ trends WNW-ESE (Figures 10 and 11). The two northernmost acoustic basement upraises $(X$ and $S$ on Figure 10 ) are cropping-out to the surface at $20^{\circ} 05^{\prime} \mathrm{S}$ and $19^{\circ} 55^{\prime} \mathrm{S}$, along a small $\mathrm{N} 135^{\circ} \mathrm{E}$-trending ridge and a volcano (Figure 11) that culminate at $2400 \mathrm{~m}$ and $1720 \mathrm{~m}$, respectively. The $20^{\circ} 05^{\prime} \mathrm{S}$ upraise deepens eastward within the Loyalty Basin.

\subsubsection{Interpretation of the Structural Map}

The structural map (Figure 11) allows to define the relative ages of the fault sets:

1. The NW-SE direction, that parallels the general trend of New Caledonia, the Loyalty system, the western edge of the North-Loyalty Basin, characterises the New Caledonia-Loyalty Basin boundary structurally controlled by a westward-dipping normal fault. The general NW-SE trend of the Loyalty system slightly changes north and south of about $20^{\circ} 10^{\prime} \mathrm{S}$ to $\mathrm{N} 135^{\circ} \mathrm{E}$ and $\mathrm{N} 125^{\circ} \mathrm{E}$, respectively.

2. The NNW-SSE direction characterises the Loyalty Ridge's blocks bounded north and south by WSWENE faults. The NNW-SSE trends of the canyon located at $21^{\circ} \mathrm{S}$ between Ouvéa and Lifou and the channel in the Loyalty Basin, at $20^{\circ} 20^{\prime} \mathrm{S}$, $165^{\circ} 40^{\prime} \mathrm{E}$ are structurally controlled by this fault set.

3. The WSW-ENE-trending faults that crosscut the Loyalty Ridge are either vertical-throw faults bounding the ridge's horsts or strike slip faults that offset the ridge either sinistrally at $19^{\circ} 20^{\prime} \mathrm{S}$ and $20^{\circ} 15^{\prime} \mathrm{S}$, or dextrally at $20^{\circ} \mathrm{S}$ (Figure 11). At this latitude, south of l'Astrolabe reef, a major WSWENE-trending fault extends from $164^{\circ} 55^{\prime} \mathrm{E}$ to $166^{\circ} \mathrm{E}$ and crosscuts the Loyalty system. This fault, located where the basin abruptly deepens to the north, probably corresponds to a vertical-throw fault. However, magnetic data indicate that the NW-SE-trending lineations of the Loyalty basin and ridge, respectively negative and positive, are dextrally offset from about $30 \mathrm{~km}$ along this transverse fault. Furthermore, seismic reflection data reveal that the WSW-ENE-trending fault zone, characterised by an upraise of the acoustic basement, outcrops westwards near $20^{\circ} 05^{\prime} \mathrm{S}$ ( $\mathrm{X}$ on Figure 10), at its junction with the NW-SE-trending New Caledonia - Loyalty Basin boundary (Figure 11). We interpret the $20^{\circ} \mathrm{S}$ WSW-ENE fault as a fracture zone, confirming previous studies of Bitoun et Récy (1982). This pre-existing potential weak zone is recently reactivated into a dextral strike-slip fault.

4. WNW-ESE directions are present between the $20^{\circ} 40^{\prime} \mathrm{S} \mathrm{SW}-\mathrm{NE}$-trending high and $20^{\circ} \mathrm{S}$, along the eastern margin of New Caledonia and within the central part of the Loyalty Basin. These trends are, to the west, normal faults bounding the $20^{\circ} 40^{\prime} \mathrm{S}$ high northern flank, and to the east, scarps that abut against the NNW-SSE-trending margin of the Loyalty Ridge. 


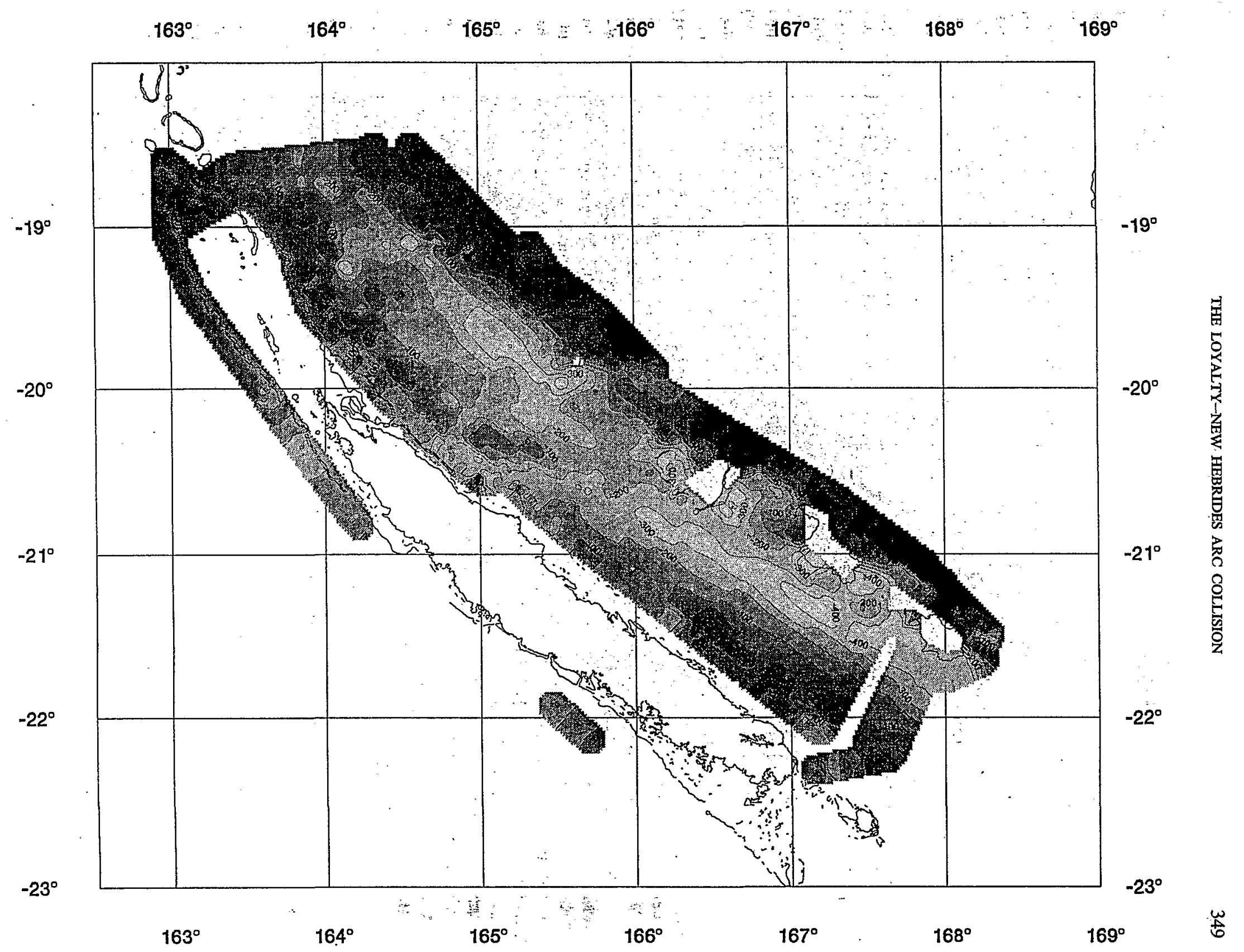

Fig. 8. Magnetic anomaly map of the Northern Box (ZoNéCo 2 cruise). Mercator projection WGS84, iso-anomales are contoured at $100 \mathrm{nT}$ intervals. 
Y. LAFOY ET AL.

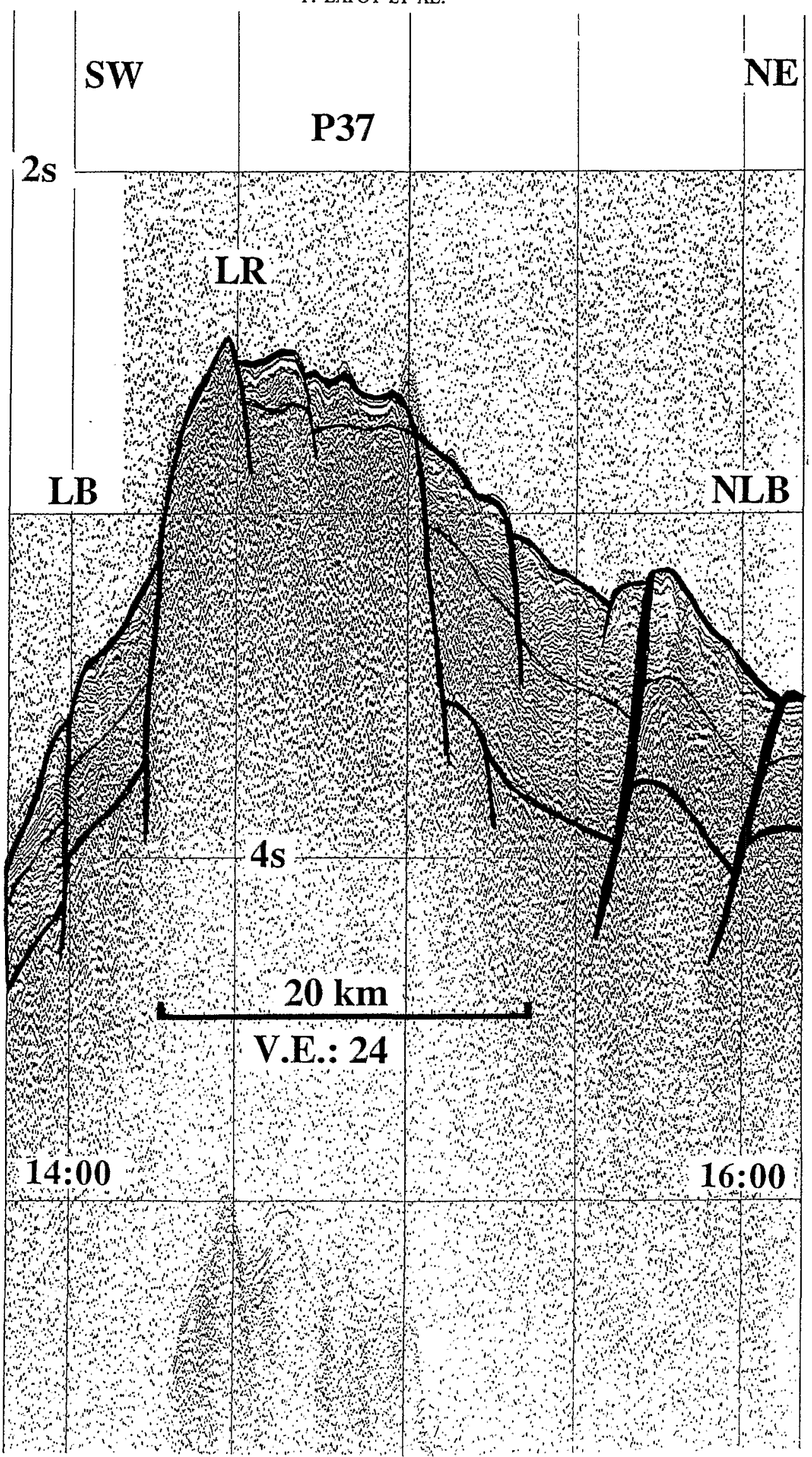




\section{Discussion}

In contrast to other subduction zones, the shallow seismicity in the New Hebrides Arc cannot be described easily due to the structural complexity of both the subducted and overlying plates (Louat et al., 1988). Bathymetric irregularities such as the d'Entrecasteaux fracture zone and the Loyalty Ridge occur on the subducted plate near the plate boundary.

Between $14^{\circ} 30^{\prime} \mathrm{S}$ and $17^{\circ} \mathrm{S}$, the subduction of the $\mathrm{d}^{\prime}$ Entrecasteaux zone forces the north and the south section of the New Hebrides Arc to separate rigidly away from the central block, and develops strike-slip motion along the lateral boundaries of the central block (Collot et al., 1985).

Although on the scale of the Loyalty Ridge collision physical indentation does not really occur (i.e. the New Hebrides trench is still present, recorded shallow seismicity on the subducting plate indicates mainly normal faulting), the coupling between lower and upper plates may be strong enough to generate horizontal compressive stresses.

Within the collision zone, Monzier et al. (1990) and Monzier (1993) found evidence for the accretion of Loyalty Ridge blocks on the inner wall of the New Hebrides trench, and interpreted it as due to the resistance of the ridge to subduction. They identifed that the interplate thrust zone shifted towards the trench and the compressive front jumped on the outer trench wall. According to these authors, a different evolution of the convergence occurs north and south of $22^{\circ} \mathrm{S}$ where a W-E sinistral strike-slip fault affects the arc and the edge of the downgoing plate.

West of the collision zone, along the Loyalty system basins and ridges, Bitoun et Récy (1982) published an isochron map of the acoustic basement based on seismic reflection profiles. They identified rises of the acoustic basement located near $17^{\circ} 15^{\prime} \mathrm{S}, 18^{\circ} 40^{\prime} \mathrm{S}$, $20^{\circ} 10^{\prime} \mathrm{S}$, and $23^{\circ} \mathrm{S}$, and interpret these sills as WSWENE-trending aseismic fracture zones that crosscut the basin. However, these authors report two earthquakes of magnitude 3.5 and 3 (1979) aligned on the $20^{\circ} 10^{\prime} \mathrm{S}$ sill.

Despite the absence of reliable focal mechanism solutions, we think that these two earthquakes may indicate recent reactivation of the WSW-ENE-trending fault zone, through strike slip motion. The $20^{\circ} \mathrm{S}$

$\leftarrow$ Fig. 9. ZoNẻCo 2 seismic line P37 that crosses the Loyalty Ridge horsts. For location, see Figure 2. Vertical Exaggeration: 25; Vertical scale: Sec.Two-Way-Time; LB: Loyalty Basin; LR: Loyalty Ridge; NLB: North-Loyalty Basin.
WSW-ENE-trending dextral strike-slip fault, probably recent as it affects the whole Loyalty system and outcrops at the junction with the New Caledonia Loyalty Basin boundary, confirms the dextral strikeslip component of the $21^{\circ} 30^{\prime} \mathrm{S}$ earthquake, east of Maré (Monzier, 1993).

The identification of the Loyalty system structural features shown in Figure 12, is based on the interpretation of the swath bathymetry, seismic reflection and magnetic data acquired during the ZoNéCo 1 and ZoNéCo 2 cruises.

North of the Loyalty Ridge-New Hebrides Arc collision zone, the $20^{\circ} \mathrm{S}$ WSW-ENE dextral fault system is interpreted as due to the early effects of collision with the New Hebrides Arc. According to Monzier (1993), north of $22^{\circ} \mathrm{S}$, the intense collision does not totally prevent the convergence, normal to the trench and driven by the subduction of the oceanic lithosphere of the North-Loyalty Basin. We interpret the $20^{\circ} \mathrm{S}$ WNW-ESE dextral system as a boundaring sliding fault zone within the northern segment of the Loyalty system (Lafoy et al., 1995b). North of $20^{\circ} \mathrm{S}$, the $\mathrm{N} 135^{\circ}$ E-trending part of the Loyalty system is dominated by the subduction of the North-Loyalty Basin oceanic crust. South of $20^{\circ} \mathrm{S}$, between this latitude and $22^{\circ} \mathrm{S}$, the $\mathrm{N} 125^{\circ} \mathrm{E}$-trending part is subjected to the Loyalty-New Hebrides collision.

South of the Loyalty Ridge-New Hebrides Arc collision zone, south of $23^{\circ} 50^{\prime} \mathrm{S}$, magnetic and seismic reflection data support a sinistral motion along the WSW-ENE strike-slip faults. These faults crosscut the generally NNW-SSE-trending Loyalty system: Therefore, the WSW-ENE sinistral fault system in the southern segment of the Loyalty system is interpreted as due to the early effects of collision with the New Hebrides Arc (Lafoy et al., 1995a). South of $23^{\circ} 50^{\prime} \mathrm{S}$, the NNW-SSE-trending Loyalty system is dominated by the subduction of the South-Fiji Basin oceanic crust subjected to fracturing by the WSW-ENE sinistral faults. Between $23^{\circ} 50^{\prime} \mathrm{S}$ and $22^{\circ} \mathrm{S}$, the arc microplate is probably strongly coupled with the Australian plate (Monzier, 1993) and the Loyalty system is subjected to the Loyalty-New Hebrides collision.

The NNW-SSE trend that structurally controls the Loyalty system is present on the New Caledonian mainland (Figure 12). A main fault separates the units of the "central chain" to the west, and the "ophiolites" to the east (Paris, 1981; Cluzel et al., 1994). The NNWSSE trend therefore might be an inherited structural direction as it affects both New Caledonia and the Loyalty system. We think that this trend might have been reactivated through extension related to the Australian plate lithospheric bulge. 

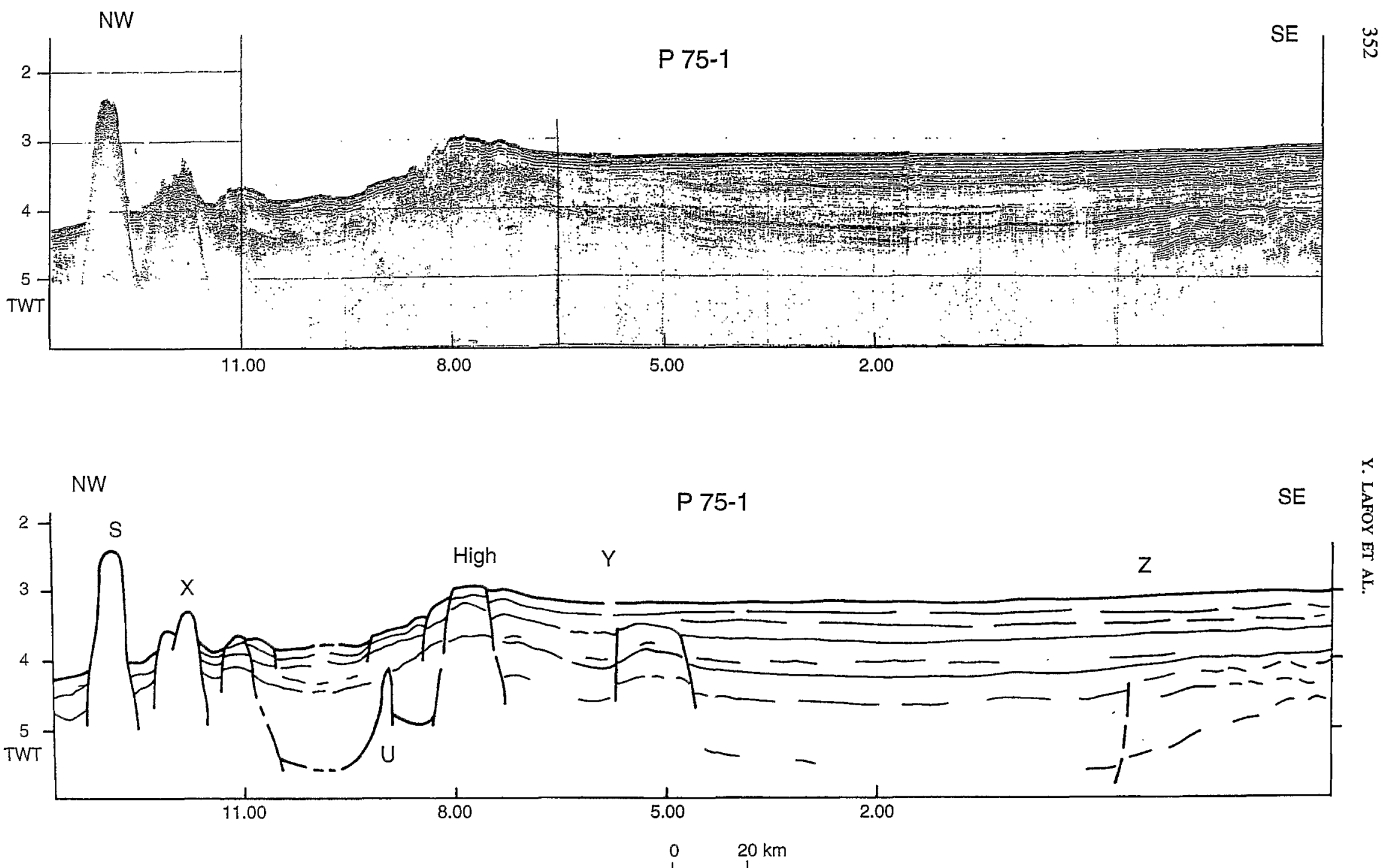

Fig. 10. ZoNéCo 2 seismic line P75-1 that crosses the Loyalty Basin. For location, see Figure 2. Vertical Exaggeration: 25; Vertical scale: SecTwo-Way-Time; S: $19^{\circ} 55^{\prime} \mathrm{S}$ seamount; $\mathrm{X}: 20^{\circ} 05^{\prime} \mathrm{S}, \mathrm{N} 135^{\circ}$ E-trending ridge; U, Y: acoustic basement upraises north and south of the $20^{\circ} 40^{\prime} \mathrm{S}$ structural high northeastward extension; Z: fault that delimits to the southeast a basement upraise. 


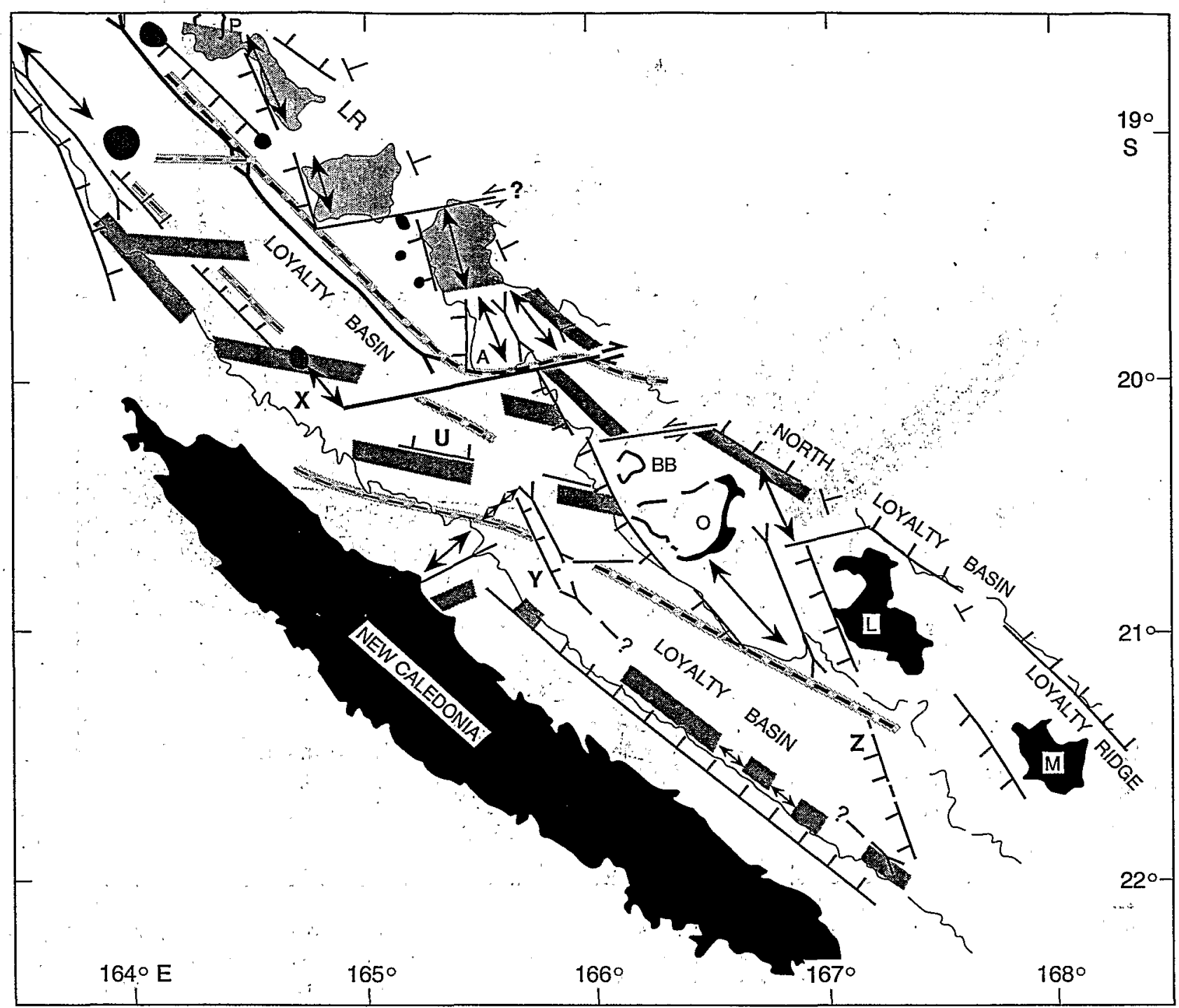

Fig. 11. Structural map of the Northern Box. For Figure caption see Figure 6. LR: Loyalty Ridge; P: Pétrie Reef; A: Astrolabe Reef; BB: Beautemps-Beaupré Atoll; O, L, M: Ouvéa, Lifou and Maré islands; X, U, Y, Z: see Figure 10 for caption.

Sinistral strike-slip faults that offset the Loyalty Ridge $\mathrm{N} 135^{\circ} \mathrm{E}$ and $\mathrm{N} 125^{\circ} \mathrm{E}$-trending guyots at $19^{\circ} 20^{\prime} \mathrm{S}$ and $20^{\circ} 15^{\prime} \mathrm{S}$, respectively, probably pre-date the recent collision.

As stated by Monzier (1993), the onset of the collision is probably recent (began some 300000 years ago). However, we think that the Loyalty Ridge probably influences, since about $3 \mathrm{Ma}$ when the activity of the North Fiji Basin N-S spreading axis started (Auzende et al., 1988), the subduction at the southern arcuate New Hebrides trench, through its action on the bulge of the downgoing plate. On the overriding Pacific plate, the Loyalty-New Hebrides collision may have caused the activity of the $22^{\circ} \mathrm{S} \mathrm{W}-\mathrm{E}$ sinistral fault (Monzier, 1993) that crosscuts the southern part of the North Fiji Basin (Figure 12), and that probably represents the recent southern boundary between the Australian and Pacific plates.

\section{Conclusions}

New bathymetric and geophysical data were acquired at the southern and northern segments of the Loyalty 


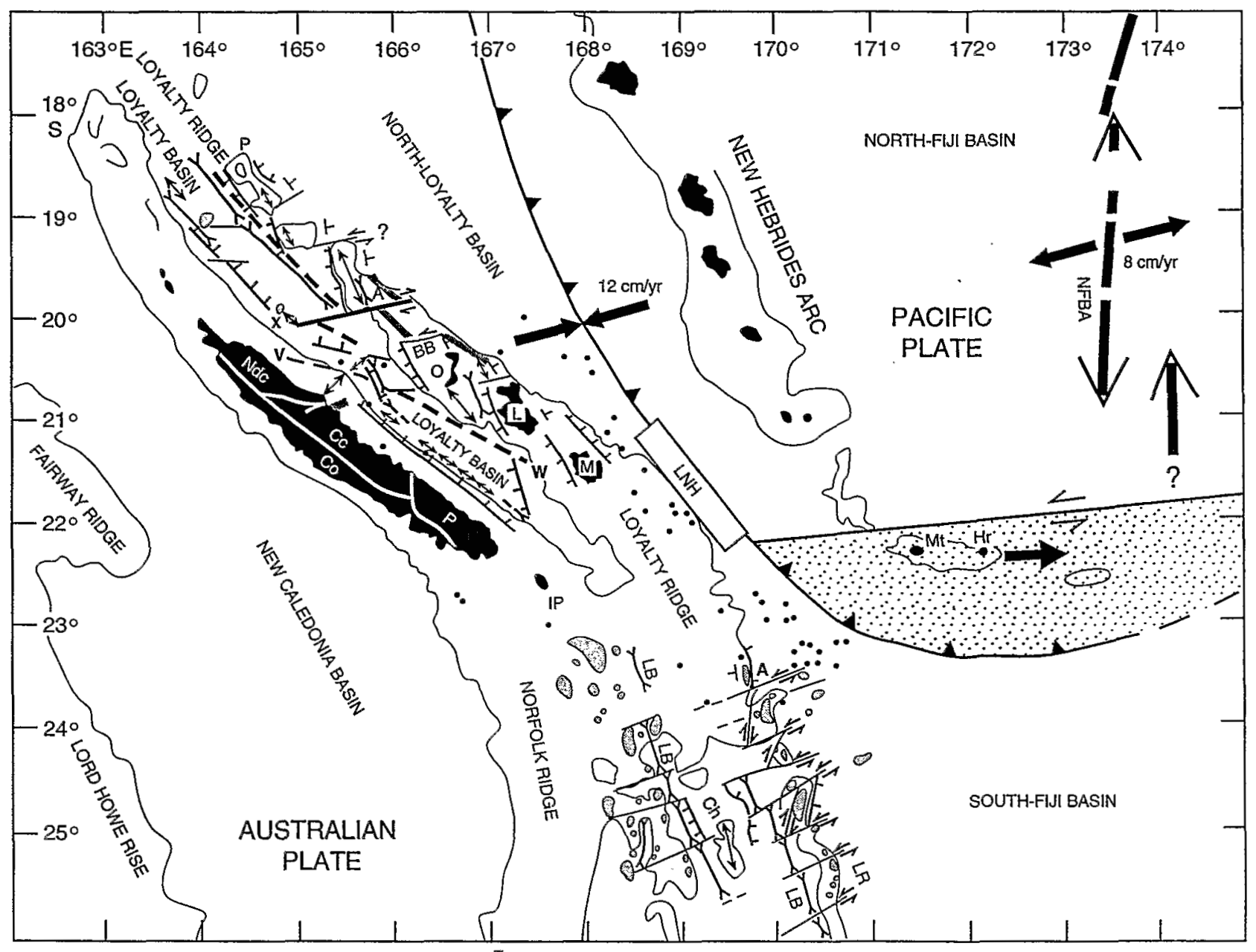

Fig. 12. Interpretative sketch of the Loyalty - New Hebrides collision (LNH). For abbreviations and symbols, see previous Figures. 1: positive magnetic lineations along the Loyalty Ridge; 2: negative magnetic lineation within the Loyalty Basin; 3: guyots and seamounts; 4: shallow earthquake distribution on the subducted plate (from Monzier, 1993, with year-1979 earthquakes of magnitude 3.5 and 3 reported by Bitoun et Récy, 1982); LB: Loyalty Basin; Ch: Central high; LR: Loyalty Ridge: V-W: probable eastern edge of the New Caledonian ophiolite; Co, Ndc, Cc, P: Onland New Caledonian geological Units "Côte Ouest, Nord-Calédonien, Chaíne Centrale, Péridotites", respectively (simplified from Cluzel et al., 1994); NFBA: North Fiji Basin Axis; $8 \mathrm{~cm} / \mathrm{y}$ : NFBA spreading rate (from Auzende et al., 1988); Shaded: Matthew (Mt) - Hunter ( $\mathrm{Hr}$ ) microplate (modified from Monzier, 1993).

system during the ZoNéCo 1 and 2 cruises, respectively. These data reveal the along-strike horst and graben structure of the Loyalty Ridge and the asymmetric morphology of the Loyalty system.

Along the southern segment of the Loyalty system, south of the Loyalty Ridge-New Hebrides Arc collision zone, in spite of sparse shallow seismicity that indicates normal faulting on the down-bending Australian plate, magnetic and seismic reflection data support a sinistral motion along the WSW-ENE faults. South of $23^{\circ} 50^{\prime}$ S, WSW-ENE strike-slip faults crosscut the generally NNW-SSE-trending Loyalty system - Norfolk/New Caledonia Ridge. The WSWENE sinistral fault system in the southern segment of the Loyalty system is interpreted as due to the early effects of collision with the New Hebrides Arc. South of $23^{\circ} 50^{\prime} \mathrm{S}$, the subducted South-Fiji Basin oceanic crust is fractured by WSW-ENE sinistral faults, whereas north of $23^{\circ} 50^{\prime} \mathrm{S}$ the eastern edge of the Loyalty system is subjected to the Loyalty-New Hebrides collision.

Along the northern segment of the Loyalty system, north of the Loyalty Ridge-New Hebrides Arc collision zone, magnetic and seismic reflection data give 
evidence for a W.SW-ENE dextral strike-slip system, confirming the sole known strike-slip earthquake mechanism solution identified on the Australian plate, near $21^{\circ} 30^{\prime} \mathrm{S}$. Therefore, we interpret the $20^{\circ} \mathrm{S}$, WSWENE dextral fault in the northern segment of the Loyalty system as resulting from the early effects of collision with the New Hebrides Arc. The WSW-ENE strike-slip fault is interpreted as a boundaring sliding fault zone with, north of $20^{\circ} \mathrm{S}$, subduction of the North-Loyalty Basin oceanic crust, and south of this latitude, collision between the Loyalty system and the New Hebrides Arc.

The Loyalty-New Hebrides collision is inferred from our data, both by the recent fracturing of the Loyalty system (at $20^{\circ} \mathrm{S}$ and south of $23^{\circ} 50^{\prime} \mathrm{S}$ ), and by the uplift of the central part of the Loyalty Basin. This uplift probably. took place along the $20^{\circ} 40^{\prime} \mathrm{S}$, SW-NE-trending structural high that marks morphological changes in both the Loyalty Basin and the New Caledonia eastern margin.

South of the $20^{\circ} 40^{\prime} \mathrm{S}$ high, the NW-SE-trending negative magnetic lineation that extends southward within the Loyalty Basin, could represent the eastern edge of the New Caledonian ophiolite.

The NNW-SSE trend, that structurally controls the Loyalty system south and north of the Loyalty-New Hebrides collision zone, and that occurs on New Caledonia, is interpreted as an inherited structural direction. This trend may have been reactivated through extension related to bulging of the Australian plate adjacent to the trench.

We interpret the morphology, structure and evolution of the Loyalty system as resulting from the combined effects of the Australian plate lithospheric bulge, the active Loyalty-New Hebrides collision, and the overthrust of the New Caledonian ophiolite.

\section{Acknowledgements}

The ZoNéCo 1 and ZoNéCo 2 cruises were carried out under the ZoNéCo programme, aimed at understanding the geology and geodynamics and providing detailed information on the marine resources of the two surveyed areas. We thank the Territory and the three Provinces of New Caledonia, the research organisations Ifremer, Orstom and the French University of the Pacific (UFP). We thank the captains of the R/V L'Atalante and their crew for their expertise during the ZoNéCo 1 and 2 surveys. We also acknowledge the Genavir and Ifremer technical staff for the on board acquisition and processing of the data.

\section{References}

Auzende, J. M., Lafoy, Y. and Marsset, B., 1988, Recent Geodynamic Evolution of the North Fiji Basin (SW Pacific). Geology 16, 925929.

Baubron, J. C., Guillon, J. H. and Récy, J., 1976, Géochronologie par la Méthode K/Ar du Substrat Volcanique de l'île Maré Archipel des Loyauté (Sud-Ouest Pacifique). Bull. BRGM, (2), IV, 3, 165-175.

Bitoun, G. and et Récy, J., 1982, Origine et évolution du bassin des Loyauté et de ses bordures après la mise en place de la série ophiolitique de Nouvelle-Calédonie, in Equipe de Géologie-Géophysique du Centre ORSTOM de Nouméa. Contribution à l'étude Géodynamique du Sud-Ouest Pacifique. Travaux et Documents ORSTOM 147, 505-539:

Cluzel, D., Aitchison, J., Clarke, G., Meffre, S. et Picard, C., 1994, Point de vue sur l'évolution tectonique et géodynamique de la Nouvelle-Calédonie. $\dot{C} \cdot R$ A Ácad. Sci., t. 319, Série II, 6, 683690.

Collot, J. Y., Missegue, F. and Malahoff, A., 1982, Anomalies gravimétriques et structure de la croûte dans la région de la NouvelleCalédonie: enracinement des péridotites, in Equipe de GéologieGéophysique du Centre ORSTOM de Nouméa. Contribution à l'étude géodynamique du Sud-Ouest Pacifique. Travaux et Documents ORSTOM 147, 549-564.

Collot, J. Y., Daniel, J. and Burne, R. V., 1985, Recent Tectonics Associated with the Subduction/Collision of the d'Entrecasteaux Zone in the Central New Hebrides. Tectonophysics 112, 325356.

Daniel, J., Dugas, F., Dupont, J., Jouannic, C., Launay, J., Monzier, $M$. et Récy, J., 1976, La zone charnière Nouvelle-Calédonie Ride de Norfolk (S.W. Pacifique) - Résultats des dragages et interprétation. Cah. ORSTOM, sér.Géol. 1, 95-105.

Dubois, J., Launay, J. and Récy, J., 1974, Uplift Movements in New Caledonia-Loyalty Islands Area and their Plate Tectonics Interpretation. Tectonophysics 24 (1/2), 133-150.

Dubois, J., Launay, J., Récy, J. and Marshall, J., 1977, New Hebrides Trench: Subduction Rate from Associated Lithospheric Bulge. Can. J. Earth Sci. 14, 250-255.

Dupont, J., Lafoy, Y., Pautot, G., Le Suavé, R., Cluzel, D., Missegue, F., Grandperrin, R., Hénin, C., Voisset, M., Durand Saint Omer, L., Gautheron, L., Butscher, J., Mollard, L., Rakoia, M. et le groupe ZoNéCo à bord de L ATALANTE, 1995, Etude morphostructurale de la zone sud des rides Nouvelle-Calédonie et Loyauté (ZEE de Nouvelle-Calédonie, Pacifique Sud-Ouest). $C$. R. Acad. Sci. Paris, t. 320, Série IIa, 211-218.

Kroenke, L. W., 1984, The New Caledonia: The Norfolk and Loyalty Ridges, chap. 2, Cenozoic Tectonic Development of the Southwest Pacific with a Contribution by Peter Rodda, Committee for Coordination of Joint Prospecting for Mineral Resources in South Pacific Offshore Areas, Suva, FIJI, Tech. Bull. 6, 15-28.

Lafoy, Y., Dupont, J., Missegue, F., Le Suavé, R. et Pautot, G., 1995a, Effets de la collision "ride des Loyauté - arc des NouvellesHébrides" sur la terminaison sud de 1 "ensemble "Nouvelle-Calédonie-Loyauté". C. R Acad. Sci. Paris, t. 320, série IIa, 11011108.

Lafoy, Y., Missegue, F., Cluzel, D., Voisset, M., Saget, P., Lenoble, J. P., Rigaut, F. et Bouniot, E., Cornec, J., De Souza, K., Gallois, F., Garioud, N., Grenard, P., Lanckneus, J., Lehodey, P., N 'Diaye, M., Perchoc, Y., Perrier, J., 1995b, Morphostructure du segment septentrional du "système" Loyauté (bassin et ride), Sud-Ouest Pacifique: résultats de la campagne ZoNéCo 2, C. R. Acad. Sci., t. 321, série IIa, 1009-1016. 
Louat, R., Hamburger, M. et Monzier, M., 1988, Shallow and Intermediate-Depth Seismicity in the New Hebrides Arc: Constraints on the Subduction Process, in Greene, H. G. et Wong, F. L. (eds.), Geology and Offshore Resources of Pacific Island Arcs, Vanuatu Region, Circum-Pacific Council for Energy and Mineral Resources, Houston, Texas, Earth Sci. Ser. 8, 329-356.

MacFarlane, A., Carney, J. N., Crawford, A. J. and Greene, H.G ., 1988, Vanuatu: A Review of the Onshore Geology, in Greene, H. G. and Wong, F. L. (eds.), Geology and Offshore Resources of Pacific island Arcs-Vanuatu Region, Circum-Pacific Council for Energy and Mineral Resources, Houston, Texas, Earth Science Series 8, 45-91.

Monzier, M., 1993, Un modèle de collision arc insulaire-ride océanique. Evolution sismo-tectonique et pétrologique des volcanites de la zone d'affrontement arc des Nouvelles-Hébrides Ride des Loyauté. Thèse Université Française du Pacifique, Nouméa, 2 vol., 322 p., I carte annexe.

Monzier, M., Daniel, J. et Maillet, P., 1990, La collision "Ride des Loyauté/Arc des Nouvelles-Hébrides" (Pacifique Sud-Ouest).
Oceanologica Acta, spécial 10, Actes du colloque: Tour du Monde "Jean Charcot", Paris, 1989, 43-56.

Paris, J. P., 1981, Géologie de la Nouvelle-Calédonie: un essai de synthèse. Mémoire BRGM 113, 279 p., 1 carte H.T. (2 coupures).

Pontoise, B., Collot, J. Y., Missegue, F. et Latham, G., 1982, Sismique réfraction dans le bassin des Loyauté: Résultas et discussion, in Equipe de Géologie-Géophysique du Centre ORSTOM de Nouméa. Contribution à l'étude géodynamique du SudOuest Pacifique. Travaux et Documents ORSTOM, 147, 541548.

Ravenne, C., Dunand, J. P., de Broin, C. E. et Aubertin, F., 1982, Les bassins sédimentaires du Sud-Ouest Pacifique, in Equipe de Géologie-géophysique du Centre ORSTOM de Nouméa. Contribution à l'étude Géodynamique du Sud-Ouest Pacifique. Travaux et Documents ORSTOM 147, 461-477.

Weissel, J. K., Watts, A. B., Lapouille, A., Karner, G. and Jongsma, D., 1977, Preliminary Results from Recent Geophysical Investigations in Marginal Basins of Melanesia. EOS Trans., A.G.U. 58,504 . 


\section{Marine Geophysical Researches / Volume 18 Nos. 2-4 June 1996}

\section{Special Issue}

\section{Seafloor Mapping in the West, Southwest and South Pacific: Results and Applications O.R.S.T.O.M. Guest Editors Centre de Nouméa JEAN-MARIE AUZENDE and JEAN-YVES COLLOT ${ }^{\text {BIBLIOTHEQUE }}$}

JEAN-CLAUDE SIBUET / Introductory Ñote

JEAN-MARIE AUZENDE and JEAN-YVES COLLOT /,Seafloor Mapping in the West, Southwest and South Pacific: Foreword

$119-121$

STEPHANE CALMANT and NICOLAS BAUDRY / Modelling Bathymetry by Inverting Satellite Altimetry Data: A Review

$123-134$

VICOLAS BAUDRY and STEPHANE CALMANT / Seafloor Mapping from High-Density Satellite Altimetry

AKESHI MATSUMOTO / Gravity Field Derived from the Altimetric Geoid and its Implications for the Origin, Driving Force and Evolution of Microplate-Type Marginal Basins in the Southwestern Pacific

IHU-KUN HSU, JEAN-CLAUDE SIBUET, SERGE MONTI, CHUEN-TIEN SHYU and CHARSHINE LIU / Transition between the Okinawa Trough Backarc Extension and the Taiwan Collision: New Insights on the Southernmost Ryukyu Subduction Zone

/LADIMIR BENES and STEVEN D. SCOTT / Oblique Rifting in the Havre Trough and its Propagation into the Continental Margin of New Zealand: Comparison with Analogue Experiments

:ERNANDO MARTINEZ and BRIAN TAYLOR / Backarc Spreading, Rifting, and Microplate

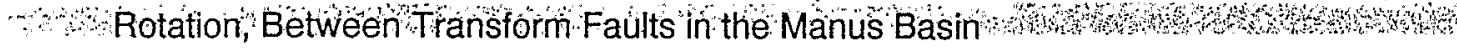
GEORGES BUFFET, GIOVANNI DE ALTERIIS, JÉRÔME DYMENT, JEAN GOSLIN, EULÀLIA GRÀCIA-MONT, YO IWABUSHI, PHILIP JARVIS, MASATO JOSHIMA, ANNE-MARIE KARPOFF, TAKESHI MATSUMOTO, HÉLĖNE ONDRÉAS, BERNARD PELLETIER and OLIVIER SARDOU / Active Oceanic Spreading in the Northern North Fiji Basin: Results of the NOFI Cruise of R/V L'Atalante (Newstarmer Project) AUZENDE and YVES LAGABRIELLE / Variability of the Axial Morphology and the Gravity Structure along the Central Spreading Ridge (North Fiji Basin): Evidence for Contrasting Thermal Regimes 